\title{
立ち作業用椅子の有無における 生体諸機能と産業疲労
}

○吉藤 宏哉 (松下電工), 吉村 勲, 松井 利樹, 森 健一（関西大学）

\section{Physiological Functions and Industrial Fatigue on the Chair for Standing Works.}

\author{
Hiroya YOSHIFUJI(Matsushita Electric Works Co.,Ltd.), \\ Isao YOSHIMURA, Toshiki MATSUI \& Ken'ichi MORI(Kansai Univ.)
}

\section{1はLめ)}

作業効率の向上を常に要求される産業の場 では, 生産ライン作業やレジ作業, ピッキング 作業などで, 立位作業方式の採用が増加して いる.これらの作業の多くは，場所が固定的な 立位での作業で動作範囲が比較的狭く,また 上肢を中心とした作業方式となっている.さら には，同種あるいはいくつかの異なる作業を同 時に担当する多能工化体制での作業実施方 式が目立ってきた. そこで, 立位作業方式の持 つ作業領域の大きさといら利点を損なわず，作 業継続に伴う負担の軽减を目的とした立ち作 業用椅子の採用に着目した。

そこでの作業者の生体諸機能や疲労の評定 は, 生理・主観・客観の 3 機能側面を総合的に 評価することにより可能とされる.よって 3 機能 側面からの総合評価法を用い，立ち作業用椅 子を用いた場合と用いない場合での作業方式 において比較・検討を行った。

\section{2 \% 法}

本報では，視覚情報にもとづいた作業である こと, 上肢の使用を中心とした単調な繰り返し 動作であること，立位作業であっても頻繁な移 動行動を伴わず狭い動作範囲内での作業であ ることなどを考慮し，図 1 に示すような $3 \mathrm{~m}$ の移 動を伴う立位姿勢での視覚検索型 VDT 作業 を対象とし, 立ち作業用椅子の有無による 2 種 の作業方式のもとでの試行とした.

作業時間は, 一連続作業時間 40 分, 50 分 または 60 分間を 4 回繰り返し,それぞれの一 連続作業の間に休款 10 分間を組み合わせた 全 3 通りの作業編成 A， B ，C とした. また, 各作業編成の前後には 30 分間ずつの安静時 間を設けた。

生理的機能の測定項目は, 筋骨格系の評 価指標として, 左足腓腹筋上部において非接 触で測定可能な皮膚表面温度および皮虚色
を, 循環器・呼吸器系の指標として心拍数と血 圧值を,さらに中枢神経機能の評価指標として CFF 值を採用し, すべて 10 分間隔で同時刻 に測定した. 客観的機能としては VDT 作業に おける正答率を採用し， 10 分間隔ごとに集計 した. 主観的機能では自覚症状しらべを採用 し, 視覚系, 筋骨格系, 精神系の 3 区分 (各 10 項目)について 5 段階で回答する方法とし, 安 静時および各作業終了時に調査した.

立ち作業用椅子については, 被験者が軽く もたれかかれる程度の高さ(座面上端点を殿溝 部に合わせる) で前傾角度を 14 度とし, 椅子 の位置や向き, 角度などはすべて固定した.

被験者は実験作業および自覚症状しらべに 習熟した健康な男子学生 4 名である.

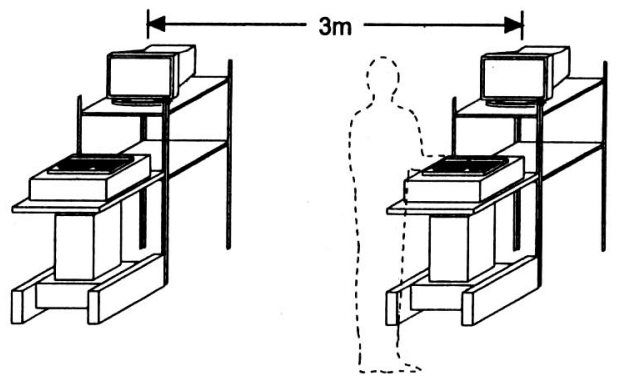

立ち作業用椅子を用いない場合

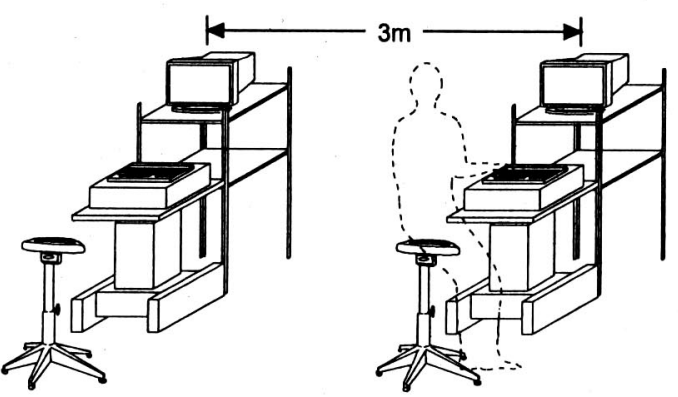

立ち作業用椅子を用いた場合

図 1 実験作業方式 


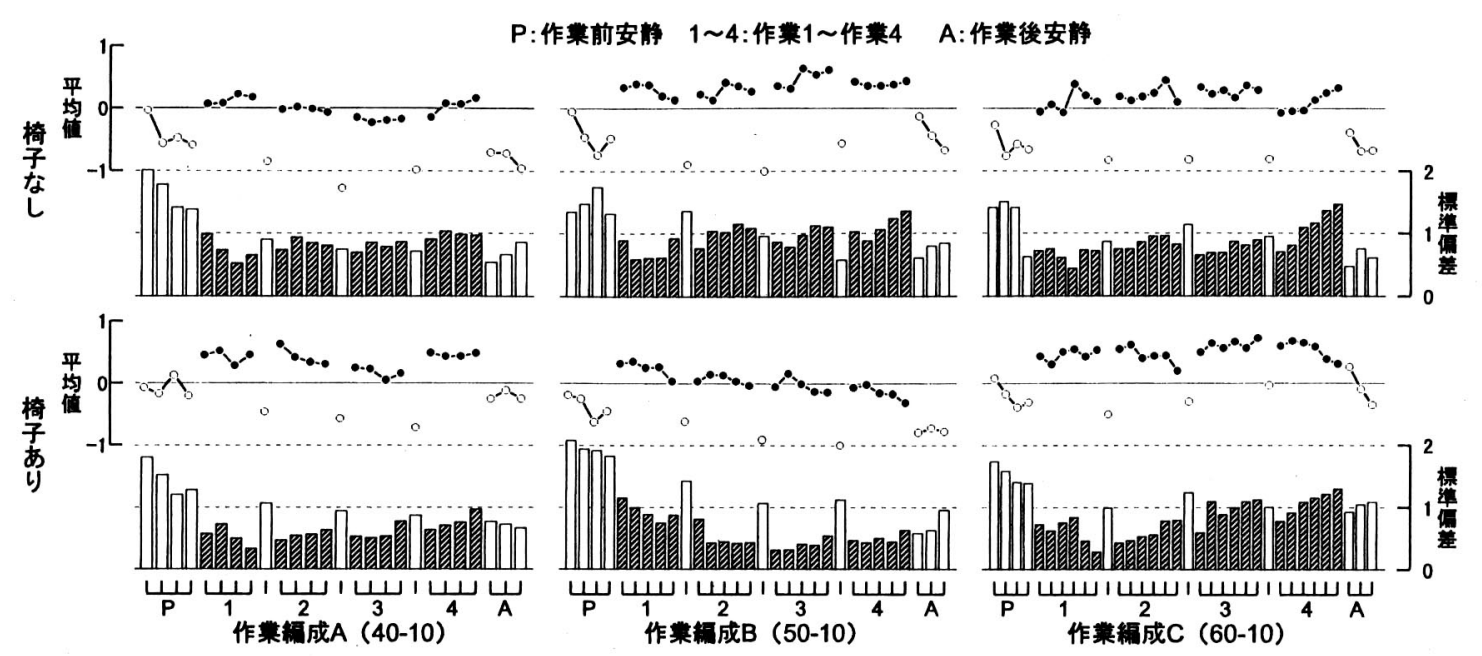

図 2 生理的機能の統合化（標準得点）

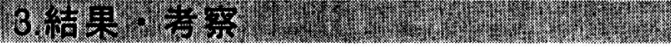

生理的諸機能はそれぞれが固有の閾値で の変化傾向を示す.よってこれらを統一的な生 理的機能の変動現象としてに評価するため, それぞれを標準得点化(平均を 0 ，分散を $1^{2}$ に基準化)ののち, 標準得点の平均値と標準 偏差に統合化（図 2 )を行った。一般的には, 標準得点の平均値は, 作業の継続に伴い下降 傾向を示す.この現象を生体の諸調節系の活 動機能の低下と考えると, 生体の促進機能が 優勢な正方向での推移から，徐々に抑制機能 が強くなり負方向での推移になるものと推察さ れる. また, 標準偏差は作業前安静時より下降 傾向ののち, 生体機能の恒常性維持に乱れが 生起することで生理的各機能の変動が增大化 ずるものと考えられる. 本試行での標準得点の 平均値は, 椅子を用いない場合に比較して椅 子を用いる場合において有意 $(\mathrm{p}<.01)$ に高い值 となる. 標準得点の標準偏差は, 椅子を用いな い場合が用いた場合に比較し有意 $(\mathrm{p}<.01)$ に高 い值で推移する結果となった. よって立ち作業 用椅子の導入により, 生理的な側面での負担 の軽減となり, 結果として統合化された生理的 機能が良好な変化推移になると考えられる.

客観的機能である作業出来高の結果より, 立ち作業用椅子の有無による有意な差は示さ れなかった. 立ち作業用椅子の導入には肉体 的な負担の軽减を可能とする反面, 覚醒水準 への影響や作業能率低下の可能性などが懸
念されるが, 本試行条件のもとではその影響は 認められなかった。

自覚症状の平均訴え得点は, 全体的に作業 の継続に伴い増大化傾向を示しており, 作業 時間が長い作業編成ほどその傾向は顕著なも のとなる.しかし，椅子を用いた場合において は, その増大化の傾向は少なくなる. 椅子を用 いない場合での総訴え得点は $\mathrm{p}<.05$, 筋骨格 系で $\mathrm{p}<.01$ で有意に大きくなるが, 視覚系, 精 神系での訴えには有意な傾向は認められなか った，筋骨格系における訴えの項目では，足・ 腰がだるい・痛いといった訴えが椅子を用いな い場合において特に多くなっている.よって立 ち作業用椅子を用いることで，笳骨格系での主 観的疲労, 特に腰・脚部への負担が軽減化で きることが推察される.

\section{5わり1=}

採用した立ち作業用椅子は，座るというより もむしろ体を支える程度のもので, この椅子の 導入により作業への機動性が低下しないことを 目的としたものである.この椅子を用いた場合 での生理的および主観的機能側面が良好な 変化推移となった.

よって採用した椅子の導入により，作業能率 への影響が発生せず腰・脚部を中心とした肉 体的負担の軽減が可能となることが示された. 従って, 立ち作業用椅子の使用の検討は, より 良い作業システムを構築するための有効な手 段の一つと考えられる. 